\title{
Long-term impacts of wildfire and logging on forest soils
}

2

3

4

5

6 8 Australian Capital Territory, Australia.

9

10

11

12

13

14

15

16

17

18

19

20

21

22

23

24

25

26

27

28

29

30

31

32

33

34

列

*corresponding e-mail: elle.bowd@anu.edu.au

15

(1)

18

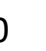

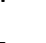

Elle J. Bowd ${ }_{1}^{*}$, Sam C. Banks 2 , Craig L. Strong 1 and David B. Lindenmayer 1

${ }_{1}$ Fenner School of Environment and Society, The Australian National University, Canberra,

${ }_{2}$ Research Institute for Environment and Livelihoods, College of Engineering, IT and the

Environment, Charles Darwin University, Darwin, Northern Territory, Australia. 


\section{ABSTRACT}

Soils are a fundamental component of terrestrial ecosystems, and play key roles in biogeochemical cycles and the ecology of microbial, plant and animal communities. Global increases in the intensity and frequency of ecological disturbances are driving major changes in the structure and function of forest ecosystems, yet little is known about the long-term impacts of disturbance on soils. Here we show that natural disturbance (fire) and human disturbances (clearcut logging and post-fire salvage logging) can significantly alter the composition of forest soils for far longer than previously recognized. Using extensive sampling across a multi-century chronosequence in some of the tallest and most carbon-dense forests worldwide (southern Australian, mountain ash (Eucalyptus regnans) forests), we provide compelling evidence that disturbance impacts on soils are evident up to least eight decades after disturbance, and potentially much longer. Relative to long-undisturbed forest (167 years old), sites subject to multiple fires, clearcut logging or salvage logging were characterized by soils with significantly lower values of a range of ecologically important measures at multiple depths, including available phosphorus and nitrate. Disturbance impacts on soils were most pronounced on sites subject to compounding perturbations, such as multiple fires and clearcut logging. Long-lasting impacts of disturbance on soil can have major ecological and functional implications. 
Natural disturbances such as fire are major drivers of the structure and function of terrestrial ecosystems worldwide, and influence key biotic and abiotic patterns and processes $1-4$.

Climate change and increases in human disturbances, such as logging, have altered natural fire regimes, resulting in an increase in large-scale fires across terrestrial ecosystems over the past few decades 1,5,6. These compounding disturbances are driving significant changes in the structure and function of ecosystems 7,8 .

While the effects of natural and human disturbances are well characterized for biotic communities, little is known about their long-term impacts on the abiotic components of soil environments, despite their importance for ecosystem function9-11. Soils play key roles in (1) the demography, interspecific interactions and community structure of plant and microbial communities, (2) biogeochemical cycles, (3) biomass production and environmental filtering and buffering, and (4) climate change mitigation through the sequestration of carbon and other greenhouse gases12-17. Limited knowledge about the impacts of disturbances on soils hinders the ability to predict the long-term responses of ecosystems to increasing natural and human disturbance10,16,18,19. In a period of rapid, global environmental and climatic change during which disturbances such as fire and anthropogenic landuse changes are predicted to increase and intensify, it is critical to quantify their respective impacts on soils to facilitate management and planning3,20,21.

Here, we quantify the impact of natural disturbance (fire) and human disturbances (clearcut and post-fire salvage logging) on soil measures across a multi-century chronosequence in the mountain ash forests of southeastern Australia. Typical fire regimes in these forests are characterized by infrequent, high-intensity fires that have historically occurred every $75-150$ years22. However, the frequency of these fires has increased and some areas have experienced multiple high-severity fires over the past century, including those in 1926, 1932, 1939, 1983 and most recently in 20098. Fires in 1939, 1983 and 2009 burned large areas of 
mountain ash forest ( $>150,000$ ha in $1939,17,250$ ha in 1983 and 53,500 ha in 200923). In addition, these forests have been subject to clearcut logging since the 1970s and post-fire salvage logging since the late 1930s8,24. Climatic changes within southeastern Australia are predicted to increase the prevalence of hot and dry conditions over the next few decades 25 . These predictions, coupled with the increasing coverage of high-severity- fire-prone logging regrowth (aged 7-35 years) will potentially increase the frequency of high-intensity standreplacing fires in these forests20,21,25,26.

From 729 soil cores collected across 81 sites, we used generalized linear models to investigate the influence of nine disturbance history categories varying in stand age $(8,34,78$ and 167 years), fire frequency $(0,1,2$ and 3 fires in recorded history since 1850), clearcut and salvage logging events and environmental variables on measures of organic carbon, macro soil nutrients (ammonium nitrogen (ammonium), nitrate nitrogen (nitrate), available phosphorus, available potassium, sulfur), micronutrients (boron (hot $\mathrm{CaCl} 2$ ), diethylene triamine pentaacetic acid (DTPA) iron, DTPA manganese, DTPA copper, DTPA zinc), exchangeable cations (exc.) (exc. aluminium, exc. calcium, exc. magnesium, exc. Potassium and exc. sodium), soil chemistry $(\mathrm{pH}(\mathrm{CaCl} 2)$, electrical conductivity (conductivity)), sand/silt/clay (\%) and soil moisture (\% dry mass) (gravimetric moisture content) from two depths of forest soil $(0-10 \mathrm{~cm}$ and $20-30 \mathrm{~cm}) 27$.

\section{Multi-decadal disturbance impacts on forest soils}

We discovered that fire, clearcut logging and salvage logging significantly influenced soil measures in the $0-10 \mathrm{~cm}$ and $20-30$ cmlayers of soil. Significant effects were evident up to at least eight decades post-fire and three decades post-clearcut logging $(\mathrm{P}<0.001$ to $\mathrm{P}=0.05)$ (Supplementary Tables 3 and 4). For instance, nitrate and available phosphorus were significantly lower across the chronosequence at sites burnt and/or logged and aged 78, 34 
111

and 8 years old, relative to long-undisturbed sites $(\mathrm{P}<0.001$ to $\mathrm{P}=0.05)$ (Fig. 1,

Supplementary Fig. 1 and Supplementary Table 3 and 4).

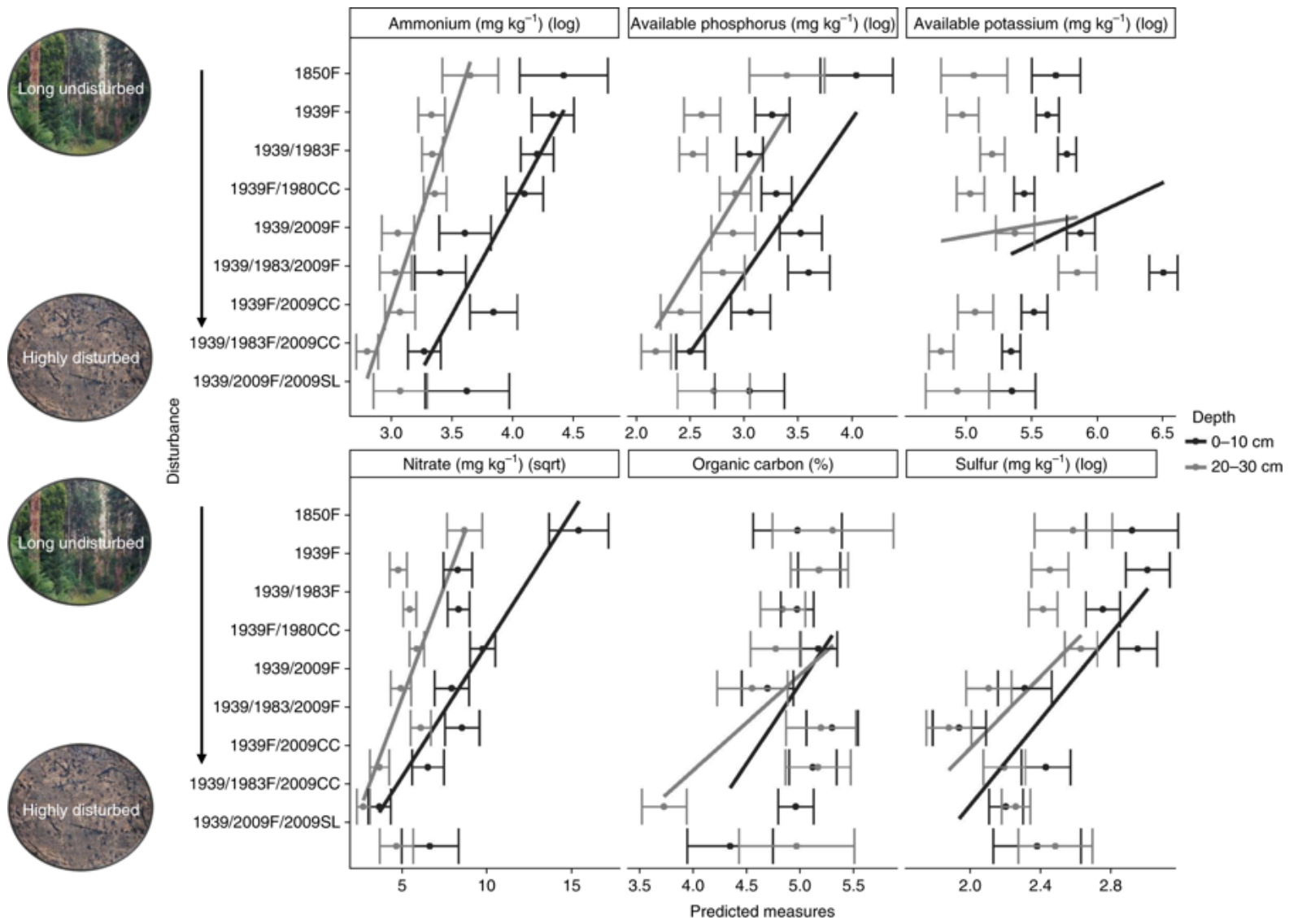

Fig. 1 | Disturbance histories influence soil measures along a multi-century chronosequence.

Predicted values of vital soil measures ( \pm standard error) in relation to disturbance history category, with trend lines. Predictions are shown for a single parent rock type (type 3:

Supplementary Table 2), Australian soil classification type (dermosol) and the mean elevation, slope and abundance of dominant plant life forms for each respective disturbance history category. See Supplementary Tables 3 and 4 for a complete list of the influence of all environmental factors. The $y$ axis lists disturbance history categories with the year of occurrence of each disturbance event $(\mathrm{F}=$ fire, $\mathrm{CC}=$ clearcut, $\mathrm{SL}=$ salvage logged $)$. Credit: photographs taken by Esther Beaton and David Lindenmayer. 
Relative to sites burnt once, forest stands burnt twice in recorded history (since 1850) were characterized by significantly lower levels of ammonium, nitrate, organic carbon, available phosphorus, sulfur, DTPA iron, boron and exchangeable aluminium cations in the $0-10 \mathrm{~cm}$ layer of soil $(\mathrm{P}<0.001$ to $\mathrm{P}=0.02)$, and ammonium, organic carbon, available phosphorus, exchangeable potassium and aluminum cations, and soil moisture in the lower layer of soil (20-30 cm depth) $(\mathrm{P}<0.001$ to $\mathrm{P}=0.04)$ (Fig. 2 and Supplementary Tables 5 and 6). In contrast, soil $\mathrm{pH}(\mathrm{CaCl} 2)$ was significantly higher in the $0-10 \mathrm{~cm}$ layer of soil, relative to sites burnt once $(\mathrm{P}=0.01)$ (Supplementary Table 5).

In forest stands burnt three times, ammonium, sulfur, exchangeable aluminium cations and DTPA iron were significantly lower in the top $0-10 \mathrm{~cm}$ of soil, relative to sites subject to one fire $(\mathrm{P}<0.001$ to $\mathrm{P}=0.05)$ (Fig. 2 and Supplementary Tables 5 and 6$)$. In contrast, available potassium and $\mathrm{pH}(\mathrm{CaCl} 2)$ were significantly higher in the $0-10 \mathrm{~cm}$ of soil $(\mathrm{P}<0.001)$ and exchangeable cations were significantly higher in the $0-10 \mathrm{~cm}$ and $20-30 \mathrm{~cm}$ layers of soil, relative to sites burnt once $(\mathrm{P}<0.001$ to $\mathrm{P}=0.02)$ (Fig. 2 and Supplementary Tables 5 and 6$)$.

Sites subject to compounding disturbances, such as multiple fires and clearcut logging or post-fire salvage logging, consistently had the lowest values of soil measures across the chronosequence,relative to long-undisturbed sites $(\mathrm{P}<0.05)$ (Fig. 1 and Supplementary Tables 3 and 4). Specifically, clearcut logging resulted in significantly lower levels of ammonium, nitrate, available phosphorus, available potassium, DTPA zinc, DTPA copper, boron and exchangeable cations in the $0-10 \mathrm{~cm}$ of soil $(\mathrm{P}<0.001$ to $\mathrm{P}=0.04)$, and available potassium, ammonium, organic carbon, available phosphorus, exchangeable cations and soil moisture in the lower $20-30 \mathrm{~cm}$ layer of soil, relative to unlogged forest $(\mathrm{P}<0.001$ to $\mathrm{P}=$ 0.04) (Supplementary Tables 5 and 6). Furthermore, clearcut logged sites had a significantly higher sand content in the $0-10 \mathrm{~cm}$ of soil, compared to unlogged sites $(\mathrm{P}=0.01)$. Salvage logged sites had significantly lower ammonium, DTPA iron, boron and exchangeable cations 
146 in the $0-10 \mathrm{~cm}$ layer of soil $(\mathrm{P}<0.001$ to $\mathrm{P}=0.04)$, and exchangeable sodium and boron in

147 the 20-30 cm layer of soil, relative to unlogged forest $(\mathrm{P}<0.001)$ (Fig. 2 and Supplementary 148 Table 5 and 6) (see Supplementary Information for further details).

149

150

151

152

153

154

155

156

157

158 


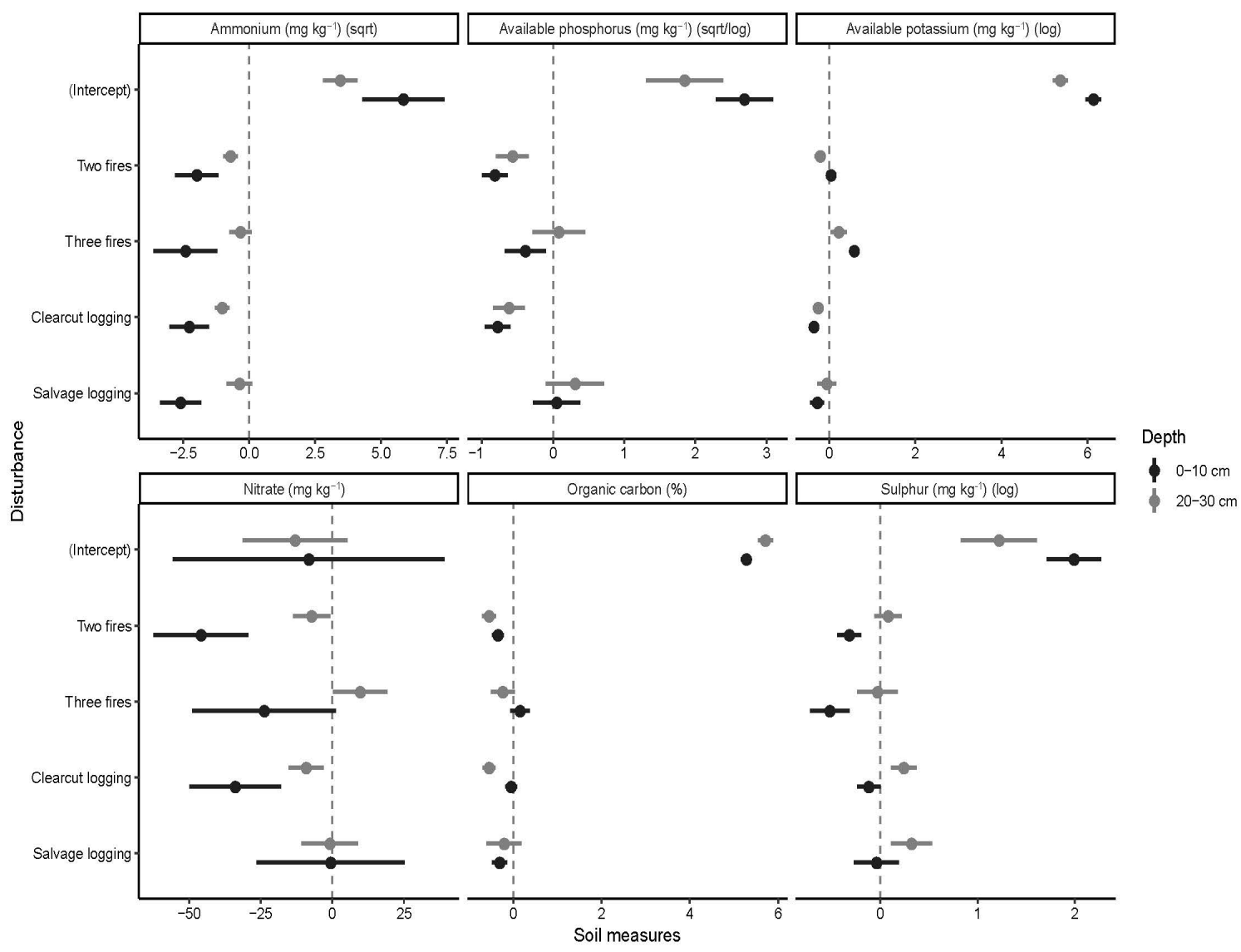

Fig. 2 | The pervasive impacts of multiple fires and logging on soil measures. Coefficients

161 from generalized linear models of each soil measure with respect to disturbance type, parent rock and Australian soil classification, elevation, slope and the abundance of dominant plant life forms (parent rock type, Australian soil classification, elevation, slope and the abundance of dominant plant life forms not displayed here). Model factors = number of fires, clearcut and salvage logging, parent rock and Australian soil classification; covariates = elevation, slope and the abundance of dominant plant life forms. Note that available phosphorus levels in the $0-10 \mathrm{~cm}$ were log-transformed, and in the $20-30 \mathrm{~cm}$ were square-root transformed. A complete list of the influence of the factors and covariates generated using these models is provided in Supplementary Tables 5 and 6. 


\section{Historical impacts on soil measures}

174 By analysing a subset of our data with identical stand age (8 years) but with different prior

175 disturbance histories, we demonstrate that fire and clearcut logging significantly influence

176 key soil measures even when controlling for age/successional effects. Sites clearcut in 2009

177 were characterized by significantly lower concentrations of nitrate, available phosphorus and

178 available potassium in the top $0-10 \mathrm{~cm}$ layer of soil $(\mathrm{P}<0.001$ to $\mathrm{P}=0.03)$, and ammonium,

179 organic carbon, available phosphorus and available potassium in the $20-30 \mathrm{~cm}$ of soil,

180 relative to similarly aged unlogged sites $(\mathrm{P}<0.001$ to $\mathrm{P}=0.04)$. Sites burnt twice (last in

181 2009) resulted in significantly lower levels of available phosphorus and sulfur in the $0-10 \mathrm{~cm}$

182 of soil $(\mathrm{P}=0.02$ to $\mathrm{P}=0.03)$ and of ammonium, organic carbon and available potassium in

183 the $20-30 \mathrm{~cm}$ of soil, relative to similarly aged sites burnt once $(\mathrm{P}<0.001$ to $\mathrm{P}=0.02)$. Sites

184 burnt three times (last in 2009) had significantly lower levels of sulfur in the $0-10 \mathrm{~cm}$ of soil

$185(\mathrm{P}<0.01)$, and higher levels of available potassium, relative to similarly aged sites burnt

186 once $(\mathrm{P}<0.001)$ (Fig. 3 and Supplementary Table 7). 


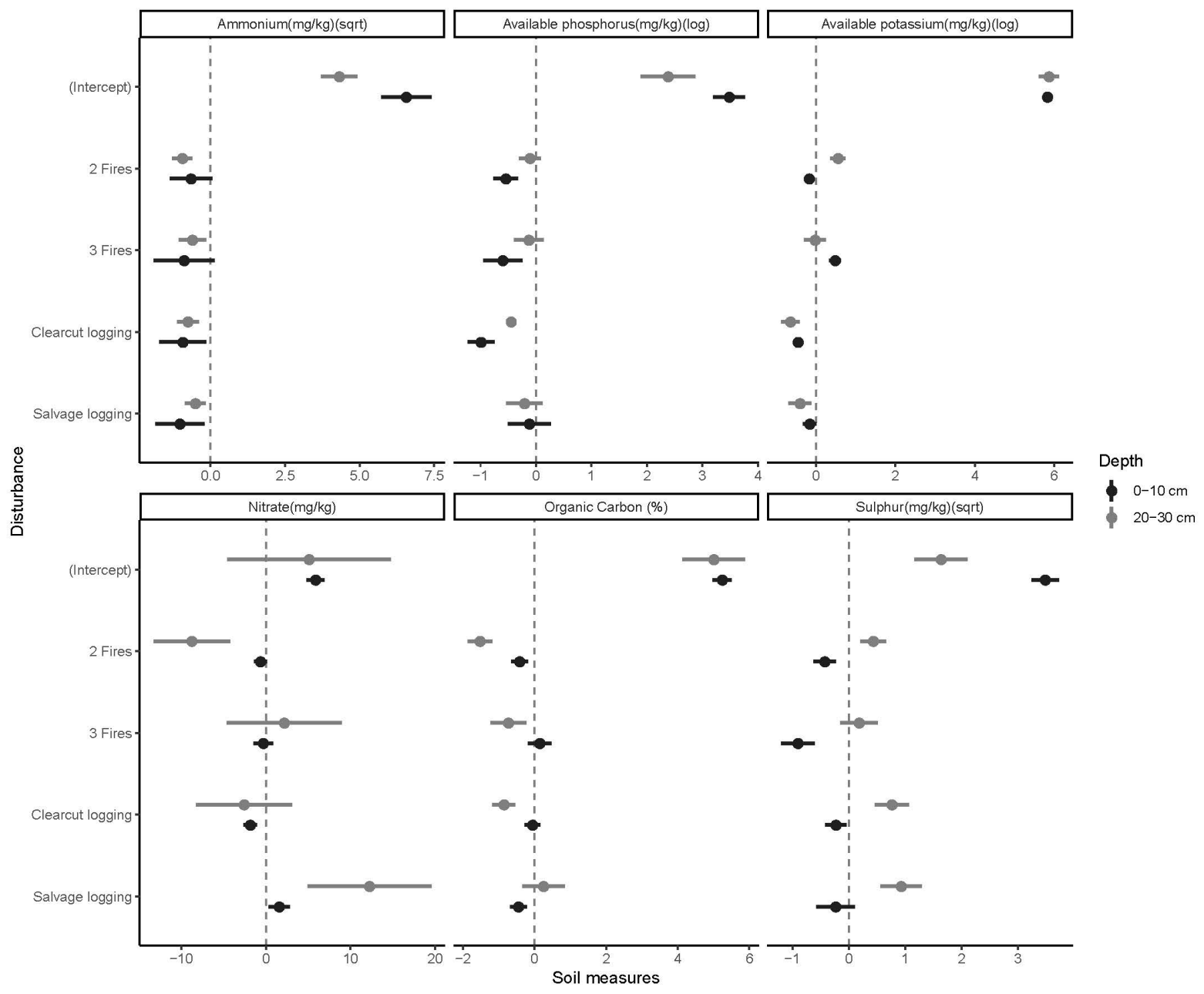

189 Fig. $3 \mid$ the impact of fire and logging in similarly aged forests on soil measures. Coefficients

190 from generalized linear models of each soil measure in similarly aged sites (last disturbed in

191 2009) with respect to disturbance type, parent rock and Australian soil classification,

192 elevation, slope and the abundance of dominant plant life forms. Model factors $=$ number of

193 fires, clearcut and salvage logging, parent rock and Australian soil classification; covariates =

194 elevation, slope and the abundance of dominant plant life forms. Note that nitrate levels in 0

$19510 \mathrm{~cm}$ were square-root transformed. A complete list of the influence of the factors and

196 covariates generated using these models is provided in Supplementary Table 7. 


\section{Implications of long-term impacts on forest soils}

200

201

202

203

204

205

206

207

We discovered that both natural and human disturbances can have long-term effects on forest soils. Soil temperatures can exceed $500{ }^{\circ} \mathrm{C}$ during high-intensity fires and result in the loss of soil nutrients, organic carbon and organic matter through volatilization and postfire erosion, which can reduce soil fertility10,18,28,29. Consistent with other studies, we found multiple fires resulted in lower levels of soil measures, across both soil depths, relative to longundisturbed forests 10 . In contrast to our discoveries, the impacts of a single fire on forest soils have been previously found to be short-term, and can result in an increase in plant productivity, decomposition and microbial activity10,18,28. However, we found that a single fire event can result in significantly lower levels of key measures, such as nitrate nitrogen and available phosphorus, that persist for at least eight decades post-fire, relative to longundisturbed sites. These long-lasting impacts also were seen in the $20-30 \mathrm{~cm}$ soil layer, which indicates that these post-fire effects may not only be attributed to changes in key soil measures, but probably indicate post-fire erosion and nutrient leaching, and reflect changes in biological processes and composition28-30.

Logging impacts observed in this study were highly significant in both the short and mid term (8 and 34 years), and result from the high-intensity combination of physical disturbance (clearing of forest with machinery) and post-logging 'slash' burning (of remaining vegetation)31. These disturbances can expose the forest floor18, compact the soil32, volatilize soil nutrients 28 and redistribute organic matter28,33, resulting in the release of large amounts of CO2 into the atmosphere (Fig. 4)33. These impacts can alter plant-soil-microbial dynamics and subsequently decomposition rates and carbon storage, and result in the leaching of dissolved organic carbon and nitrogen, and the depletion of base cations, reducing overall site productivity3,18,28,34. Given the long-lasting impacts of fire, we suggest that the logging-related depletion of key soil measures may act as a precursor for longer-term, and 
224 potentially severe changes in soil composition33. Multi-decadal logging impacts occur in 225 other large-tree, slow turnover forests, such as boreal forests (which experience losses in soil

226 carbon and nitrogen), and can take up to a century to recover3,9,18,19,28,33,35. The long-

227 lasting impacts of both fire and clearcut logging in mountain ash ecosystems indicate that the 228 abiotic soil environments of this (and possibly other) forest ecosystems may be maladapted to 229 frequent, high-intensity disturbances that exceed natural disturbance return intervals3,28.

230 Therefore, predicted changes to global disturbance patterns, such as increasing fire intensity

231 and frequency, could result in severe declines in key soil measures in the long term, with

232 major ecological and functional implications3. 


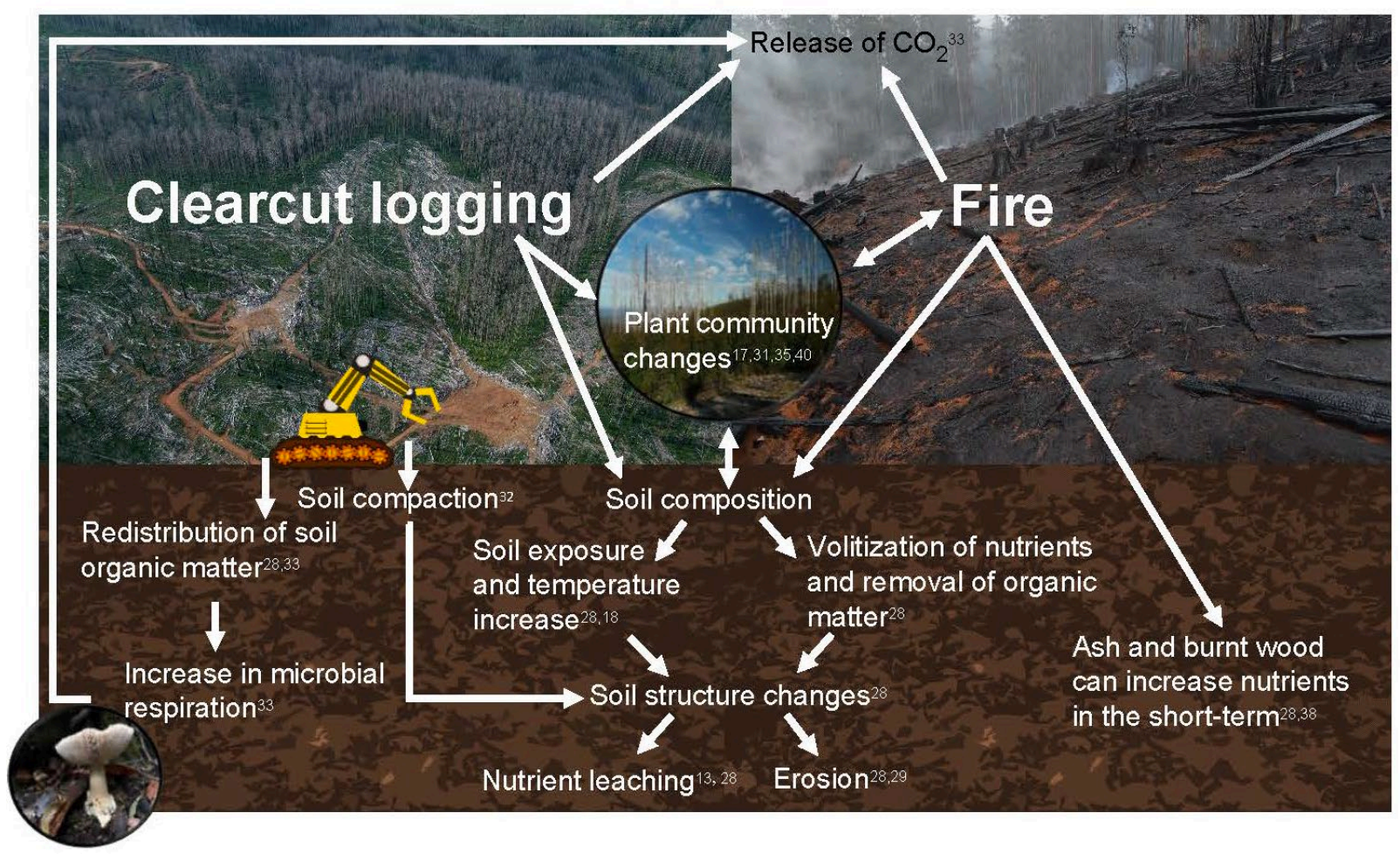

247 Fig. 4 | Post-disturbance processes and pathways that influence and impact abiotic soil

248 environments. White arrows indicate influential relationships and flow-on effects associated

249 with disturbance in soil environments. For example, fire and clearcut logging can alter the

250 structural integrity of soils, which can impede the water and nutrient holding capacity of soils

251 and subsequently result in nutrient leaching and erosion, potentially impacting plant

252 productivity. Credit: images provided by Elle Bowd, David Lindenmayer and David Blair. 
In mountain ash forests and other slow-turnover forests, vegetation rapidly regenerates after stand-replacing disturbances36,37.This growth is supported by an increase in light and the availability of phosphorus and nitrogen from surface ash deposits38. Further inputs of these key nutrients are a product of self-thinning and litterfall39, microbial activity40 and aboveground biological fixation from species such as Acacias, which can dominate postdisturbance regrowth and offset losses in nitrogen within nine years post-disturbance41. Despite these biochemical inputs, our results demonstrate that significantly lower concentrations of key nutrients such as nitrate and available phosphorus are still evident up to eight decades post-fire and three decades post logging, with the lowest measures found in highly disturbed forests subject to compounding disturbances. We did not measure the uptake rate of nutrients in the surrounding vegetation, which may explain some deficits within the soil in some ecosystems42. However, when controlling for successional stage, we found unlogged sites burnt in 2009 consistently had higher estimates of key soil measures relative to similarly aged sites logged in 2009. This comparison indicates that disturbance intensityand frequency is a major factor in determining the composition of forest soils, regardless of stand age and nutrient uptake (Fig. 3).

\section{Recommendations for forest management}

We have empirically demonstrated long-term natural and human disturbance impacts on forest soils. Climate change and human disturbances are projected to increase large standreplacing fires globally3,43,44. This will probably result in substantial long-term losses of crucial soil measures, which can effect ecosystem function and forest productivity and growth over the medium to long term18,45-47. To maintain vital soil nutrient pools and preserve the key functions that soils have in ecosystems, such as carbon sequestration and the regulation of plant and microbial community productivity, land managers should consider the impacts of current and future disturbances on soils in ecosystem assessments and land-use 
management and planning. Specifically, perturbations such as fire (outside the historical fire

285

286

287

295

296

297

298

299

300

301

302

303

304

305

306

307

308

309

310

311

312 return interval of 75-150 years22) and clearcut and post-fire salvage logging should be limited wherever possible, especially in areas previously subject to these disturbances.

Aboveground ecosystem legacies that occur in highly fertile, long-undisturbed sites, such as large old trees, are diminishing globally, and can take over a century to recover from the impacts of disturbance48. Our findings suggest that below-ground abiotic soil environments may take a similar amount of time to recover.

5

(1)

7




\section{REFERENCES}

1. Bowman, D. M. et al. Fire in the Earth system. Science 324, 481-484 (2009).

2. Fraver, S. et al. Forest structure following tornado damage and salvage logging in northern Maine, USA. Can. J. For. Res. 47, 560-564 (2017). 3. Seidl, R., Schelhaas, M. J., Rammer, W. \& Verkerk, P. J. Increasing forest disturbances in Europe and their impact on carbon storage. Nat. Clim. Change 4, 806-610 (2014).

4. Bond, W. J. J., Woodward, F. I. I. \& Midgley, G. F. F. The global distribution of ecosystems in a world without fire. New Phytol. 165, 525-537 (2005).

5. Giglio, L., Randerson, J. T. \& van der Werf, G. R. Analysis of daily, monthly, and annual burned area using the fourth-generation global fire emissions database (GFED4). J. Geophys. Res. Biogeosci. 118, 317-328 (2013).

6. Van Der Werf, G. R. et al. Global fire emissions estimates during 1997-2016. Earth Syst. Sci. Data 9, 697-720 (2017).

7. Cochrane, M. A. \& Laurance, W. F. Synergisms among fire, land use, and climate change in the Amazon. Fire Ecol. Manag. 37, 522-527 (2008).

8. Lindenmayer, D. B., Hobbs, R. J., Likens, G. E., Krebs, C. J. \& Banks, S. C. Newly discovered landscape traps produce regime shifts in wet forests. Proc. Natl Acad. Sci. USA 108, 15887-15891 (2011).

9. Diochon, A., Kellman, L. \& Beltrami, H. Looking deeper: an investigation of soil carbon losses following harvesting from a managed northeastern red spruce (Picea rubens Sarg.) forest chronosequence. For. Ecol. Manage. 257, 413-420 (2009).

10. Pellegrini, A. F. A. et al. Fire frequency drives decadal changes in soil carbon and nitrogen and ecosystem productivity. Nature 553, 194-198 (2018). 11. Watson, J. E. M. et al. The exceptional value of intact forest ecosystems. Nat. Ecol. Evol. 2, 599-610 (2018).

12. De Deyn, G. B., Raaijmakers, C. E. \& Van Der Putten, W. H. Plant community development is affected by nutrients and soil biota. J. Ecol. 92, 824-834 (2004).

13. Mckenzie, N., Jacquier, D., Isbell, R. \& Brown, K. Australian Soils and Landscapes: An Illustrated Compendium (CSIRO Publishing, Collingwood, 2004).

14. Blum, W. E. H. Functions of soil for society and the environment.

Rev. Environ. Sci. Bio/Technol. 4, 75-79 (2005).

15. Tedersoo, L. et al. Global diversity and geography of soil fungi. Science 346, 1052-1053 (2014).

16. Paustian, K. et al. Climate-smart soils. Nature 532, 49-57 (2016).

17. van der Putten, W. H. et al. Plant-soil feedbacks: the past, the present and future challenges. J. Ecol. 101, 265-276 (2013).

18. Hume, A. M., Han Chen, Y. H., Taylor, A. R. \& Han, C. Intensive forest harvesting increases susceptibility of northern forest soils to carbon, nitrogen and phosphorus loss. J. Appl. Ecol. 55, 246-255 (2018). 19. Prest, D., Kellman, L. \& Lavigne, M. B. Mineral soil carbon and nitrogen still low three decades following clearcut harvesting in a typical acadian forest stand. Geoderma 214-215, 62-69 (2014).

20. Bowman, D. M. J. S., Murphy, B. P., Neyland, D. L. J., Williamson, G. J. \& Prior, L. D. Abrupt fire regime change may cause landscape-wide loss of mature obligate seeder forests. Glob. Change Biol. 20, 1008-1015 (2014). 
21. Clarke, H. G., Smith, P. L. \& Pitman, A. J. Regional signatures of future fire weather over eastern Australia from global climate models. Int. J. Wildl. Fire 20, 550-562 (2011). 22. McCarthy, M. A., Malcolm Gill, A. \& Lindenmayer, D. B. Fire regimes in mountain ash forest: evidence from forest age structure, extinction models and wildlife habitat. For. Ecol. Manage. 124, 193-203 (1999).

23. Burns, E. L. et al. Ecosystem assessment of mountain ash forest in the Central Highlands of Victoria, south-eastern Australia. Austral. Ecol. 40, 386-399 (2015).

24. Florence, R. Ecology and Silviculture of Eucalypt Forests (CSIRO Publishing, Collingwood, 1996).

25. Commonwealth Scientific and Industrial Research Organisation (CSIRO)

Climate Variability and Change in South-eastern Australia: A Synthesis of

Findings from Phase 1 of the South Eastern Australian Climate Initiative (SEACI) (CSIRO Publishing, 2010).

26. Taylor, C., Mccarthy, M. A. \& Lindenmayer, D. B. Nonlinear effects of stand age on fire severity. Conserv. Lett. 7, 355-370 (2014).

27. Bissett, A. et al. Introducing BASE: the Biomes of Australian Soil Environments soil microbial diversity database. Gigascience 5, 21 (2016). 28. Certini, G. Effects of fire on properties of forest soils: a review. Oecologia 143, $1-10$ (2005).

29. Malvar, M. C. et al. Short-term effects of post-fire salvage logging on runoff and soil erosion. For. Ecol. Manage. 400, 555-567 (2017).

30. Wilson, C. J. Effects of logging and fire on runoff and erosion on highly erodible granitic soils in Tasmania. Water Resour. Res. 35, 3531-3546 (1999). 31. Bowd, E. J., Lindenmayer, D. B., Banks, S. C. \& Blair, D. P. Logging and fire regimes alter plant communities. Ecol. Appl. 28, 826-841 (2018).

32. Rab, M. A. Recovery of soil physical properties from compaction and soil profile disturbance caused by logging of native forest in Victorian Central Highlands, Australia. For. Ecol. Manage. 191, 329-340 (2004).

33. Zummo, L. M. \& Friedland, A. J. Soil carbon release along a gradient of physical disturbance in a harvested northern hardwood forest. For. Ecol. Manage. 261, 1016-1026 (2011). 34. Simard, D. G., Fyles, J. W., Paré, D., Nguyen, T. \& Nguyen, D. Impacts of clearcut harvesting and wildfire on soil nutrient status in the Quebec boreal forest. Can. J. Soil Sci. 81, 229-237 (2001).

35. Menge, D. N. L., Pacala, S. W. \& Hedin, L. O. Emergence and maintenance of nutrient limitation over multiple timescales in terrestrial emergence and maintenance of nutrient limitation over multiple timescales in terrestrial ecosystems. Source Am. Nat. 173, 164-175 (2009). 36. Ashton, D. H. in Fire and the Australian Biota (eds Gill, A. M., Groves, R. H. \& Noble, I. R.) 339-366 (Australian Academy of Science, Canberra, 1981). 37. Bélanger, N., Côté, B., Fyles, J. W., Courchesne, F. \& Hendershot, W. L. H. Forest regrowth as the controlling factor of soil nutrient availability 75 years after fire in a deciduous forest of Southern Quebec. Plant Soil 262, 363-372 (2004). 38. Chambers, A. B. \& Attiwill, P. The ash-bed effect in Eucalyptus regnans forest: chemical, physical and microbiological changes in soil after heating or partial sterilisation. Austral. J. Bot. 42, 739-749 (1994). 39. Polglase, P. J. \& Attiwill, P. M. Nitrogen and phosphorus cycling in relation to stand age of Eucalyptus regnans F. Muell. I. Return from plant to soil in 
litterfall. Plant Soil 142, 157-166 (1992).

40. Dijkstra, F. A. et al. Enhanced decomposition and nitrogen mineralization sustain rapid growth of Eucalyptus regnans after wildfire. J. Ecol. 105, 229-236 (2017). 41. May, B. M. M. \& Attiwill, P. M. M. Nitrogen-fixation by Acacia dealbata and changes in soil properties 5 years after mechanical disturbance or slashburning following timber harvest. For. Ecol. Manage. 181, 339-355 (2003). 42. Russell, A. E. \& Raich, J. W. Rapidly growing tropical trees mobilize remarkable amounts of nitrogen, in ways that differ surprisingly among species. Proc. Natl Acad. Sci. USA 109, 10398-10402 (2012). 43. Moritz, M. A. et al. Climate Change and disruptions to global fire activity. Ecosphere 3, 49 (2012).

44. Bowman, D. M. J. S. et al. The human dimension of fire regimes on Earth. J. Biogeogr. 38, 2223-2236 (2011).

45. Kishchuk, B. E. et al. Decadal soil and stand response to fire, harvest, and salvage-logging disturbances in the western boreal mixedwood forest of Alberta, Canada. Can. J. For. Res. 45, 141-152 (2015).

46. Turner, B. L., Brenes-Arguedas, T. \& Condit, R. Pervasive phosphorus limitation of tree species but not communities in tropical forests. Nature 555, 367-370 (2018).

47. Alvarez-Clare, S., Mack, M. C. \& Brooks, M. A direct test of nitrogen and phosphorus limitation to net primary productivity in a lowland tropical wet forest. Ecology 94, 1540-1551 (2013).

48. Lindenmayer, D. B. \& Laurance, W. F. The ecology, distribution, conservation and management of large old trees. Biol. Rev. 92, 1434-1458 (2017).

\section{ACKNOWLEDGMENTS}

The authors thank the Victorian Department of Environment, Land, Water and Planning and Parks Victoria for granting access to restricted sites, volunteers who assisted in data collection, A. Bissett for methodological advice, W. Blanchard for statistical advice, and the following groups for funding: the Paddy Pallin Foundation, Centre of Biodiversity 